\title{
Mapping the Incidences of Crime in Makurdi Metropolis, Benue State, North-Central Nigeria
}

\author{
Inah E. Okon ${ }^{1 *}$, Anthony O. Agorye², Kyegh F. Aov ${ }^{1}$ \\ ${ }^{1}$ Department of Geography and Environmental Science, University of Calabar, Calabar, Nigeria \\ ${ }^{2}$ Department of Architecture, University of Calabar, Calabar, Nigeria \\ Email: *inah.okon@unical.edu.ng
}

How to cite this paper: Okon, I.E. Agorye, A.O. and Aov, K.F. (2021) Mapping the Incidences of Crime in Makurdi Metropolis, Benue State, North-Central Nigeria. Open Access Library Journal, 8: e6577. https://doi.org/10.4236/oalib.1106577

Received: July 9, 2021

Accepted: August 24, 2021

Published: August 27, 2021

Copyright () 2021 by author(s) and Open Access Library Inc.

This work is licensed under the Creative Commons Attribution International License (CC BY 4.0).

http://creativecommons.org/licenses/by/4.0/

\section{(c) (i) Open Access}

\begin{abstract}
This paper highlights the significance of crime mapping in Makurdi metropolis using GIS applications to enhance identification, mapping and presentation of crime patterns and trends. Attribute data were obtained from police incident files while the spatial data were gotten from field work. The distribution of crimes and the variation of crime occurrences within the 5 police divisions were assessed, with B Police Division recording the highest crime incidences. Also, crime hotspots in the area were determined. The one-way ANOVA showed a statistically significant difference in the distribution of crime incidents among the 5 Police jurisdictions $(\mathrm{F}(4,100)=3.767, p<0.05)$. The study recommended the establishment of GIS units in all police stations to aid crime analysis for effective mobilization of police patrol teams.
\end{abstract}

\section{Subject Areas \\ Criminology, Information Science}

\section{Keywords}

Crime Incidents, Geographical Information System (GIS), Police Division, Crime Distribution

\section{Introduction}

Crime is an age long issue dated back to the early times of man, documented in various historical scripts such as the Bible. The rate at which crime escalates in the world today raises questions as to what the situation would be like if urgently preventive and controlled measures are not sustainably and effectively enforced. Despite the measures employed in tackling crime, its occurrence is still recurrent in villages, towns, and cities all over the world, especially in the developing climes 
which lack modern technology and equipment to check the spade of crime and violence.

The problem of crime, criminal behavior, or unlawful behavior has always posed not only a big threat to society and people but has also raised great concerns. Its prevention in society cannot be over-emphasized. Dambazau [1] defined crime as an act or omission against public interest and which is prescribed by law enacted by the legislature in the overall interests of the society, and to which prescribed punishment is attached in the event of the violation. Crime is also seen as a violation of the rules agreed to be respected by all members of the society, and upon which the rest members of the society mete sanction upon those guilty of the violation. It is for the same reason that the legal system views crime as a public and moral wrong.

The interest of different law enforcement agencies in the application of Geographical Information Systems (GIS) in mapping the incidence of crime happened simultaneously with research activities that identified criminal behaviour as well as crime patterns in the evolving field of environmental criminology [2] [3] [4] [5] [6]. Practitioner interest in crime mapping developed together with a research field devoted to offering explanations to the criticality of place in "offender behaviour and victimization" can be acknowledged to be similar to these two-pronged thrusts within geography-GIS and geographical information science [6].

The police are usually credited with being the earliest criminal justice agency to take a real interest in GIS, and continue to show remarkable interest and support for crime mapping to this day. Hirschfield et al. [7] identified "technical issues and the incompatibility of police databases" as technical issues that plagued the initial implementation of GIS in crime mapping. Other challenges included "geocoding" defined as "the method by which a street address is converted into map coordinates" problems [8] and management difficulties [9].

The current trend of crime and violence in Nigeria has reached an unprecedented height and it has raised the concern of security agencies operational in Nigeria from the Nigerian Police Force to the Nigeria Security and Civil Défense Corps. Amidst the continuous insurgency in the North East, the cattle rustlers maiming in Kaduna, Benue, and other parts of the Middle Belt, political violence in River state, the unrest in the Niger Delta, and the spate of kidnapping, armed robbery, and other crimes all over the country, the security agencies undoubtedly are doing a lot to quell the incidences of crime. However, apparently, much more is required of them. The crime problem with particular reference to Makurdi metropolis of Benue State within the past few years has been systematic with the occurrence and frequency of armed robbery, murder, kidnapping, and burglary. The frequency in the occurrence of such violent crimes has made it difficult for the police to handle it on their own. A variety of measures and techniques have been adopted to combat this menace, but these problems of violent crimes have persisted even till recent times. 
One of such measures or techniques that should be adopted in combating crime is the application of Geographic Information System (GIS) by federal, state authorities, and local security agencies in crime management and decision-making process. The widespread integration of mapping into crime prevention research and practice has gained recognition recently to both scholars and practitioners considering the rate of criminal activities the world over. The idea of mapping crime is not new and, in fact, dates back to the early 1800s in France. A review of the historical literature from that period to the present time shows several epochs during which interest in crime mapping was great but then faded dramatically [10]. Crime mapping and spatial analysis of crime are recognized as powerful tools for the study and control of crime because crime maps help police identify problems at the block [11].

Crime is not spread evenly across Makurdi like every other city. It clumps in some areas and is absent in others. This knowledge is used by city dwellers in their daily activities, avoiding some places and seeking out others. The choices of residents in selecting their neighbourhoods, schools, stores, streets, and recreation are governed partially by the understanding that their chances of being crime victims are greater in some of these places than in others. City dwellers understand that crime is not evenly distributed. They might be mistaken about the risks of some places, but they are not mistaken that their risk of being a victim of crime is not geographically constant [12].

Today, municipal administrators over the world attempt to reduce crime against persons and property and loss of human lives due to criminal activities through crime prediction and by creating databases of crime prone areas or hotspots. It has been shown by various studies that crime can be more effectively managed when crime predictions are complemented with maps of crime prone areas. The production of good crime hotspots maps involves using a tool with a broad range of functions that are capable of manipulating both spatial and attribute data. In this regard, the efficacy of the GIS can be relied upon.

Makurdi is the capital of the Benue State of Nigeria. The city is located in central Nigeria along with the Benue River and spatially at $7^{\circ} 43^{\prime} 50^{\prime \prime} \mathrm{N} 8^{\circ} 32^{\prime} 10^{\prime \prime} \mathrm{E}$. According to the National Population Commission, Makurdi had an estimated population of 239,889 and 300,377 in 2006. The major ethnic groups in the area are the Tiv, Idoma, Igede, and Etulo. The metropolis is located on the banks of Benue River, a major tributary of the Niger River. It is also located on the main narrow-gauge railway line running north from Port Harcourt, although this is not currently working. There are regular bus services linking Makurdi to neighbouring towns. Until a road-rail bridge was built in 1932, a train ferry was used to cross the Benue River. Figure 1 shows the extent of the metropolis.

\section{Literature Review}

Review of the works of Sherman and Weisburd [13] accounts for the theory of crime hotspots. The theory describes clustering of crime around places involving 


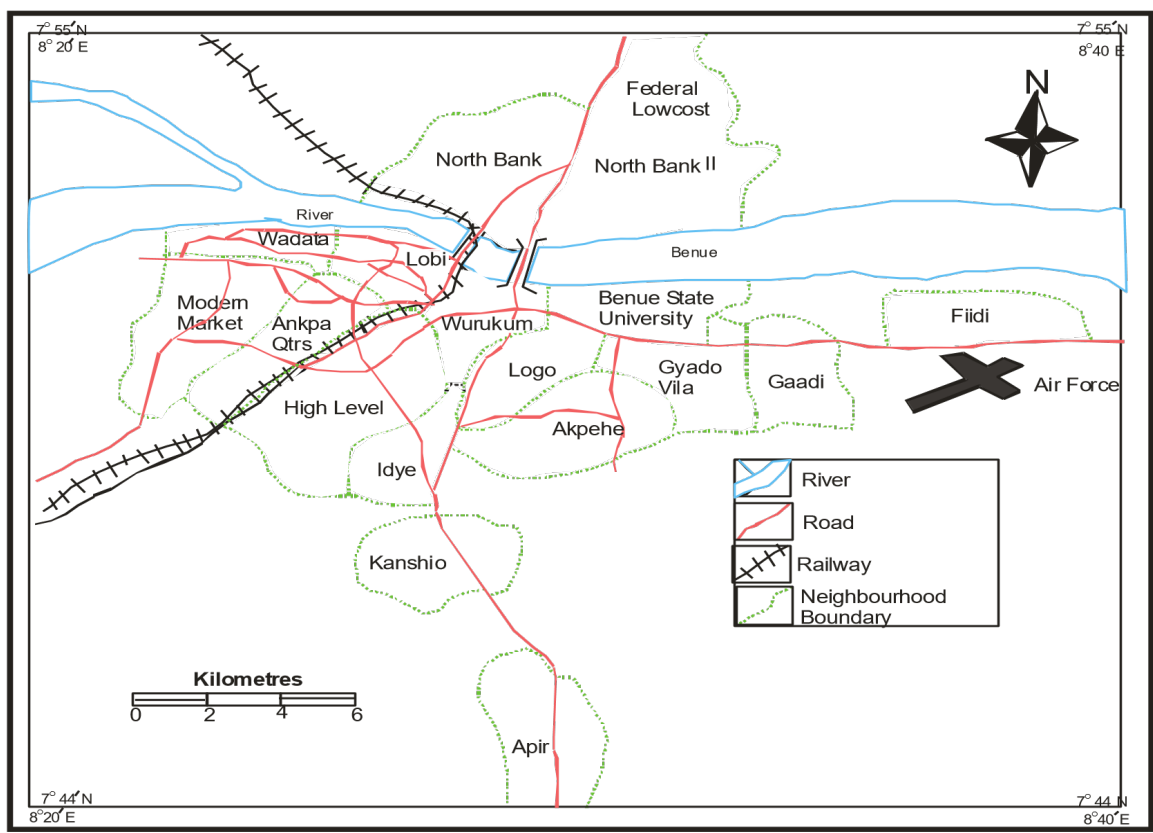

Figure 1. Makurdi metropolis.

different offenders and different targets interacting at the same place repeatedly over time. It describes areas with high crime intensity. A hotspots patrol strategy in policing can reduce total crime in a jurisdiction. Hence the emphasis by the authors on the need for hotspot maps to show crime concentration. In addition, crime pattern theory contends that offenders are influenced by the geographical nature of their daily routine activities when they search for crime opportunities. They tend to concentrate in areas that are known to them. This theory is relevant to this research as it explains why crime concentrates in those areas with high crime waves.

Theoretically, on the causes of crime, the social disorganization theory suggests that the natural ability of people to control deviancy in their neighbourhoods is impaired in some areas by constant residential turnover and net outmigration. These changes either disrupt social networks or prevent such networks from forming. Since these networks, according to disorganization theory, are responsible for most social control in neighbourhoods, their absence leads to higher levels of deviancy. Other factors, such as poverty and racism, also have been identified as undermining social networks. Also, the broken windows theory which emphasizes crime concentration as buttressed by Wilson and Kelling in their 1982 article titled Broken Windows asserts that in most well-functioning neighbourhoods, when small transgressions of social norms are not nipped at the bud, the willingness and ability of residents to enforce social order are undermined and consequently, residents withdraw from enforcing neighbourhood norms, which allows further deviancy to occur. Also, the crime opportunity theory points to crime opportunities as the principle cause of crime. For example, a dense urban neighbourhood with no off-street parking will have many 
cars parked on the street. Such an area may become an area hot spot for thefts from vehicles [12].

The usefulness of GIS in crime mapping has been noted by different literatures, some of which have been reviewed in this research. According to Fajemirokun et al. [14] in their work, "a GIS approach to crime mapping and management in Nigeria, specifically in the Victoria Island area" adopted spatial data acquisition and attribute data in their study and found out that the police station in Victoria Island is not in the best location because it is not centrally located for accessibility from other parts of the island. They suggested a Police station at zone 4 or 5, and also for equal coverage of all the areas in Victoria Island, the best location for a police station should be somewhere along the junction where Adeola Odeku and Akin Adesola streets meet.

Equally, Groff and La Vingne [15] on forecasting the future of predictive crime mapping, identified the various methods, described what is required to use them, and assessed how accurate they are in predicting future crime concentrations, or hot spots. They shifted from analysis of past incident reports to methods of delineating future crime and location for effective policing with the use of GIS. Ahmadi [11] also in his work crime mapping and spatial analysis, reiterated the importance of GIS in mapping, crime control and prevention programs. He also stressed the importance of crime maps in the study of the ecology and the locational aspects of crime, and also that maps enable areas of unusually high or low concentration of crime to be visually identified. However, he pointed out that maps are only pictorial representations of the results of more or less complex spatial data analyses. He proposed a hierarchical model dealing with crime analysis and applied it to the regional analysis of crime in Tehran. The model helped to identify spatial concentration of crimes in a specific area using what is termed area-based method in analysis. Conclusively, after determining the hot spots based on the method mentioned above, he used spatial function to find a suitable location to establish a new police station and to direct patrol to the hot spots for the reduction of crime.

Further, in the quest to critically assess the impact of crime rate on sustainable tourism in Cross River State Nigeria, Ukwayi et al. [16] in their work; the Impact of crime on sustainable tourism in Cross River State, Nigeria observed that the rehabilitation, development of tourism potentials and the recent introduction of the biggest carnival event in Nigeria has constituted a great threat to residents and tourists who have the interest to visit Cross River State and Calabar in particular as a tourism destination. The authors identified majorly one disadvantage of the Calabar Carnival as encouraging crime. Their crime report analyses show that the month of December in which the carnival is held recorded the highest crime. They, therefore, recommended that if tourism is to be sustained in Cross River, operators of resort centres should provide adequate security around their business environment, intelligence personnel should be deployed to those hotspots environment so as to monitor movements, vigilante groups should be con- 
stituted and charged with the responsibility of ensuring security in their domain, the perpetuators of crime should be arrested, charged to court and punished. These according to the scholars would help eliminate crime in the area.

Furthermore, the Geo-spatial analysis of crime in Kaduna Metropolis, Nigeria, by Ayuba, Mugu, Tanko, and Bulus [17] revealed that theft/stealing and hurting/fight ranks highest among recorded crimes with $19.29 \%$ and $16.82 \%$ respectively. From an overlay analysis of all the acquired coordinates of the crimes displayed on the composite map, the study discovered that crime incidence is highest in Tudun Wada with (15.05\%), followed by Sabon Tasha and Rigachikun with $10.24 \%$ and $10.16 \%$ respectively. The study also revealed that Tudunwada, Sabon Tasha, Rigachikun, and Rigasa are the major crime hotspots in the metropolis. An administrative map of the study area enhanced the delineation of the police districts according to the Divisional Police Headquarters Jurisdiction in Kaduna Metropolis where a total of 11 crime types were mapped. Similarly, Olajuyigbe, Omole, Bayode, and Adenigba [18] used secondary data to Neighbourhood and Correlation Analysis in GIS environment and revealed that the transport route cutting through Akure metropolis is prone to crime activity.

Benue State is not left out of the daunting incidences of criminal activities that have been affecting the world, socially, economically and politically. This study becomes important as a measure of crime prevention and management. The initiative of the Benue State government and the Nigerian Police Force in the distribution of Police Stations and out-post for effective policing and arrest of crime seems to be yielding less than the desired impact as the Benue State Security agencies are yet to adopt the proactive GIS approaches in the pursuit and arrest of crime, as this has now become a global best practice. This is crime management gap not peculiar to Benue State or Nigeria, but a common phenomenon in many parts of the developing world, and therefore the motivation for this research.

\section{Materials and Methods}

Attribute and spatial data were gathered for this research. Secondary data which has to do with crime rate, location and types of crime against persons, property and society were obtained from crime records of the Nigerian Police Force (NPF) Headquarters, Benue State Police Command, Makurdi. Data on the geographical location of the Police stations and crime addresses were collected using a hand-held Global Positioning System. The crime addresses documented as house numbers, street names and localities collected from the Police were located and the coordinates of such addresses were collected to aid in the crime mapping. The crime incident data collected showed crime occurrences in the 5 Police divisions from 2007 to 2014.

Data was analysed using descriptive, spatial and inferential techniques. Tables and maps were used to display and symbolize outputs of the analyses. Proximity and point density spatial analyst tools in the GIS environment were used to as- 
sess the coverage of policing and density of crime through crime hotspot maps which depicts the areas with agglomeration of crime. The crime hotspots map was generated using the crime point data. The point density tool calculates the magnitude per unit area from point features that fall within a neighbourhood around each cell [19]. Further, the one-way analysis of variance (ANOVA) was used in testing the formulated hypothesis that there is no significant difference in the distribution of crime amongst the police jurisdictions in Makurdi from 2007 to 2014.

\section{Results and Discussions}

\subsection{Crime Incidents and Distribution in Makurdi Metropolis}

A total of 21 criminal offences were analysed separately in relation to the study area collectively.

Table 1 shows the incidents of crime in Makurdi from 2007 to 2014 while Table 2 depicts the crime distribution under the five Police Divisions in the area within the period. The highest crime recorded in the area was theft with $155 \mathrm{oc}-$ currences, followed by culpable homicide with 97 incidences recorded. Armed robbery and robbery also recorded high incidents too with 70 and 73 incidents respectively. The least recorded crime in the area was trafficking with only 1 reported case in the 5 years period. Most of the crimes showed a significant increase over the years. For example, there were 3 reported incidents of armed robberies in 2007, 32 cases in 2013 and a reduction to 17 in 2014. Also, there

Table 1. Makurdi crime incident report (2007 to 2014).

\begin{tabular}{|c|c|c|c|c|c|c|}
\hline Variable & 2007 & 2008 & 2012 & 2013 & 2014 & Total \\
\hline Armed Robbery & 3 & 5 & 13 & 32 & 17 & 70 \\
\hline Robbery & 5 & 16 & 4 & 32 & 16 & 73 \\
\hline Rape & 3 & 5 & 5 & 16 & 1 & 30 \\
\hline Assault & 5 & 17 & 0 & 9 & 9 & 40 \\
\hline Causing Grievous hurt & 3 & 9 & 2 & 24 & 9 & 47 \\
\hline Theft & 14 & 26 & 12 & 55 & 48 & 155 \\
\hline Trespass & 5 & 4 & 3 & 4 & 3 & 19 \\
\hline Culpable Homicide & 6 & 20 & 11 & 29 & 31 & 97 \\
\hline Mischief & 4 & 4 & 1 & 10 & 12 & 31 \\
\hline Fraud/Cheating & 0 & 1 & 1 & 7 & 2 & 11 \\
\hline Unlawful Possession of firearm & 5 & 9 & 5 & 19 & 11 & 49 \\
\hline Kidnapping & 3 & 0 & 1 & 6 & 3 & 13 \\
\hline Vandalization & 1 & 0 & 1 & 1 & 0 & 3 \\
\hline Unlawful society & 4 & 11 & 7 & 5 & 4 & 31 \\
\hline Escape from lawful custody & 1 & 0 & 0 & 1 & 0 & 2 \\
\hline Fire incident & 2 & 6 & 1 & 2 & 6 & 17 \\
\hline Impersonation & 2 & 0 & 2 & 2 & 3 & 9 \\
\hline Caught in possession of Indian Hemp & 1 & 0 & 0 & 1 & 0 & 2 \\
\hline Breach of Public Peace & 0 & 1 & 2 & 1 & 3 & 7 \\
\hline Trafficking & 0 & 1 & 0 & 0 & 0 & 1 \\
\hline Breach of trust & 1 & 0 & 1 & 0 & 0 & 2 \\
\hline TOTAL & 68 & 135 & 72 & 256 & 178 & 709 \\
\hline
\end{tabular}

Source: Benue State Police Command Headquarters, Makurdi (2017). 
Table 2. Total crimes per police division.

\begin{tabular}{cccccc}
\hline Type of crime & A Div & B Div & C Div & D Div & E Div \\
\hline Armed Robbery & 11 & 26 & 14 & 7 & 12 \\
Robbery & 11 & 29 & 24 & 3 & 6 \\
Rape & 0 & 6 & 8 & 7 & 9 \\
Assault & 2 & 20 & 3 & 7 & 8 \\
Causing Grievous hurt & 1 & 28 & 10 & 2 & 6 \\
Theft & 17 & 93 & 18 & 13 & 14 \\
Trespass & 1 & 6 & 3 & 8 & 1 \\
Culpable Homicide & 14 & 36 & 31 & 9 & 8 \\
Mischief & 2 & 18 & 7 & 2 & 2 \\
Fraud/Cheating & 1 & 6 & 2 & 1 & 1 \\
Unlawful Possession of firearm & 10 & 10 & 14 & 10 & 3 \\
Kidnapping & 2 & 4 & 1 & 1 & 5 \\
Vandalization & 1 & 1 & 0 & 1 & 0 \\
Unlawful society & 8 & 4 & 8 & 10 & 1 \\
Escape from lawful custody & 0 & 1 & 1 & 0 & 0 \\
Fire incident & 1 & 10 & 4 & 1 & 0 \\
Impersonation & 2 & 4 & 2 & 3 & 0 \\
Caught in possession of Indian & 0 & 0 & 2 & 0 & 0 \\
Breach of Public Peace & 2 & 2 & 0 & 3 & 0 \\
Trafficking & 0 & 1 & 0 & 0 & 0 \\
Breach of trust & 1 & 0 & 0 & 1 & 0 \\
TOTAL & $\mathbf{8 7}$ & $\mathbf{3 0 5}$ & $\mathbf{1 5 2}$ & $\mathbf{8 9}$ & $\mathbf{7 6}$ \\
(1) & & & & &
\end{tabular}

Source: Benue State Police Command Headquarters, Makurdi (2017).

were 14 theft cases in 2007 and a progression to 48 in 2014. An overall assessment of Table 1 shows that there were 68 crime incidents recorded in 2007, doubling to 135 in 2008. The year 2012 saw a reduction of reported cases to 72 while again the figures skyrocketed to 256 in 2013 and reduced again to 178 in 2014 , thus a total of 709 in the years under study.

An assessment of crime distribution among the Police Divisions as presented on Table 2 depicted that B Division recorded the highest incidents of crime in the metropolis, followed by C Division. A Division, D Division and E Division recorded 87, 89 and 76 incidents respectively. As observed, in the B division's jurisdiction, some streets are noted for regular incidences of crime, such as Iorkyaa Ako, Inikpi, Konshisha and Katsina street. Other areas notable for crime are around Wurukum market, such as Awe Street, Onitsha Street, along New Otukpo Road, Ishaya Bakut Road, Nyiman layout. Also, robbery cases have been experienced around High-Level roundabout, Assembly Quarters, Otukpo Road, Katsina Street, Kwararafa Quarters and Ishaya Bakut Road all of B Division jurisdiction. Robbery has also been recorded in North Bank around places like; Opposite Heavy-Duty Park along Lafia Road, behind CAPS, Udei Street, Federal Low-cost housing estate extension, Veterinary layout N/bank, Yagba village, AA Rano filling station, Day spring. E division has also recorded high cases of rape with 9 cases repeatedly at Akpehe, Logo 1 and 2 as shown in Table 2. Theft is the criminal offence that has the highest record, most of which occur in B Division. Offences such as car theft, motorcycle theft, child theft, among other items were 
mostly carried out around High level, Idye, Kashio, Apir, Railway roundabout, Low level areas. Most of the Culpable Homicide cases reported in North Bank (C division's jurisdiction) occur along the river side. The proliferation of illegal firearms amongst residents of Makurdi results in another crime frequently recorded.

From Table 1, the amount of crime per Police Division within the five years considered is presented and used for the analysis to infer if there is a significant difference in the distribution of crime amongst the police jurisdictions in Makurdi. Variation was visible with 2 divisions recorded the highest cases of crime, these include $\mathrm{B}$ division $\left(\mathrm{X}_{2}\right)$ and $\mathrm{C}$ division $\left(\mathrm{X}_{3}\right)$ with 305 and 152 respectively. The least number of crimes was recorded in $\mathrm{E}$ division $\left(\mathrm{X}_{5}\right)$ with a total of 76 cases, A division $\left(\mathrm{X}_{1}\right)$ and $\mathrm{D}$ division $\left(\mathrm{X}_{4}\right)$ had 87,89 accordingly. However, Table 3 shows the output of the one-way ANOVA analysis, depicting the nature of statistically significant difference between our group means. This result depicts a statistical significant difference in the distribution of crime incidents among the 5 Police jurisdictions in Makurdi $(\mathrm{F}(4,100)=3.767, p<0.05)$, thus an acceptance of the alternate and a rejection of the null hypothesis.

\subsection{Spatial Distribution of Crime Incidents in Makurdi Metropolis}

In Figure 2, crime distribution in Makurdi metropolis is attempted. Due to repeated record of crime occurrence at certain places, spatial data was acquired only once at such locations. This brings the number of crime points on the map to 500 out of the 709 total crime incidents considered in this research. Notably, as shown in Table 4, out of the 500 points shown on the map, 216 crime points fall within less than $1 \mathrm{~km}$ radius of police coverage while 284 falls within more than $1 \mathrm{~km}$ area of police coverage as presented in. This affirms the claim that absence of security services exposes areas to crime. The buffer tool was used for proximity analysis to measure how close and how far police services exist in relation to crime spots. The police stations were buffered at 1 kilometer radius to show the extent of police coverage in each division as shown in Figure 3. The crime points were further merged with the 1 kilometer buffer to deduce the crime occurrences within and outside the police $1 \mathrm{~km}$ coverage.

The crime occurrence evidenced within the $1 \mathrm{~km}$ radius of B Division's jurisdiction as deduced from a visit to the area during this research revealed that the most likely cause of crime incidents in the area is as a result of the activities

Table 3. One-way ANOVA for distribution of crime amongst the police jurisdictions in Makurdi.

\begin{tabular}{cccccc}
\hline & Sum of Squares & df & Mean Square & F & Sig. \\
\hline Between Groups & 1755.181 & 4 & 438.795 & 3.767 & 0.007 \\
Within Groups & 11648.381 & 100 & 116.484 & & \\
Total & 13403.562 & 104 & & \\
\hline
\end{tabular}


Table 4. Crime incidents within $1 \mathrm{~km}$ of police divisions.

\begin{tabular}{cc}
\hline Police Division & Crime incidents within 1 km (2007-2014) \\
\hline A Division & 37 \\
B Division & 89 \\
C Division & 57 \\
D Division & 30 \\
E Division & 1 \\
Police Headquarters & 2 \\
TOTAL & 216 \\
\hline
\end{tabular}

Source: Benue State Police Command Headquarters, Makurdi (2017).

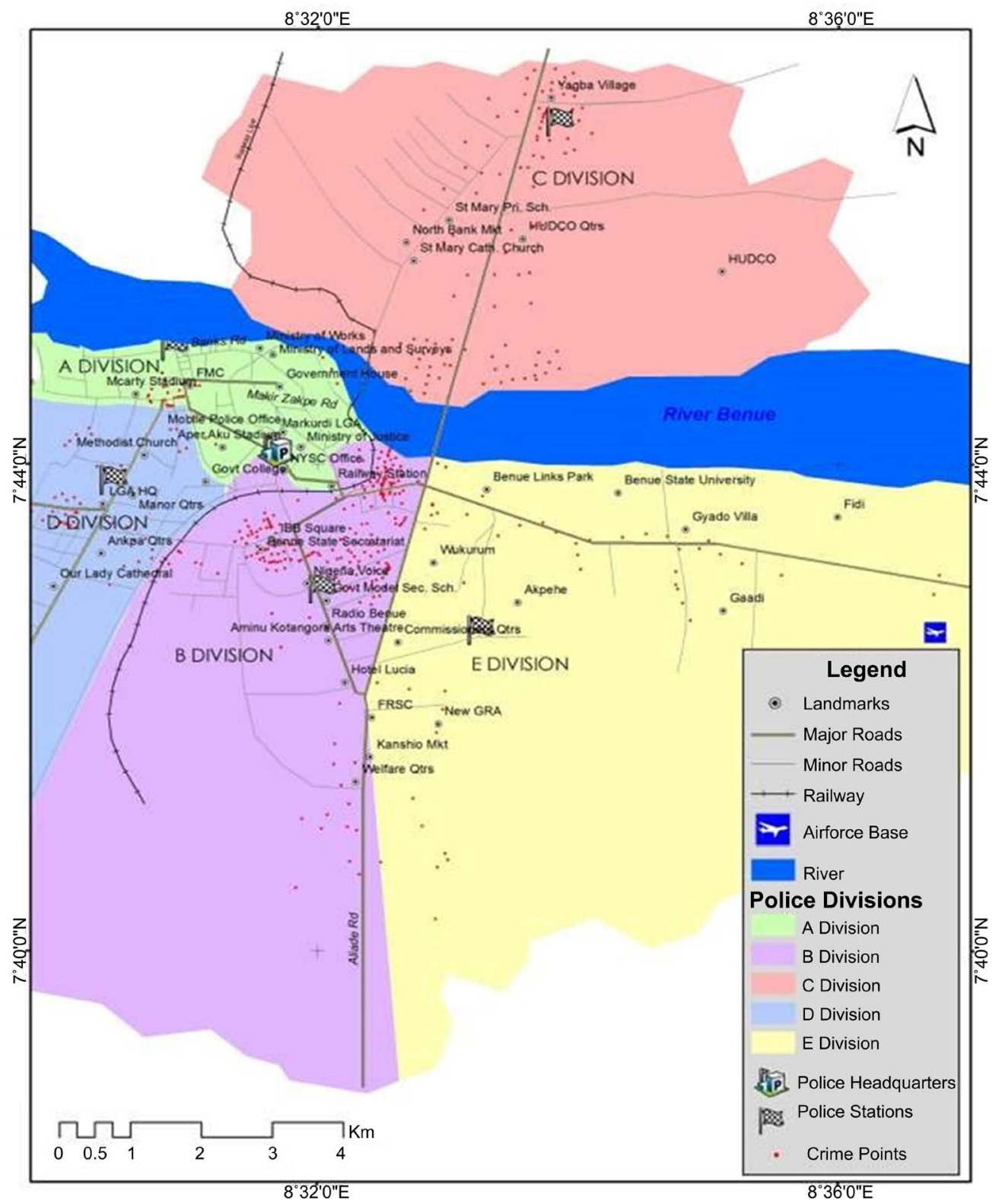

Figure 2. Makurdi showing the spatial distribution of crime. 


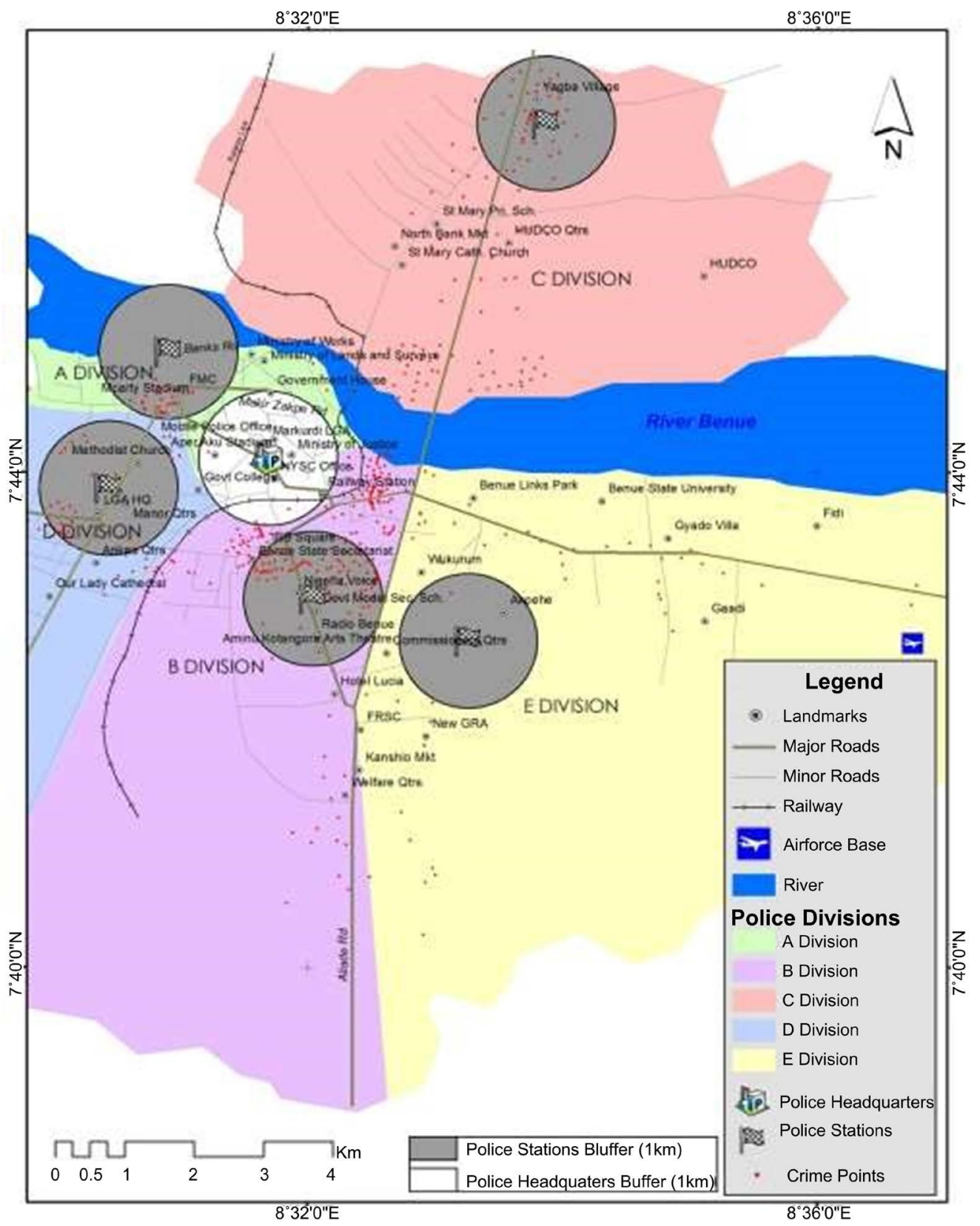

Figure 3. Makurdi showing crime within 1 kilometer buffer of Police stations.

within the area which attracts large population such that crime cannot be totally avoided. Beer parlors and several drinking joints exist around these points, such that criminals either take advantage of drunks and some people under the influence of alcohol carry out certain activities such as rape, assault, causing of grievous hurts among other offences which land their act into police incident files. Another reason for high crime within the $1 \mathrm{~km}$ radius Figure 3: Makurdi showing crime within 1-kilometer buffer of Police stations of the police stations is the presence of markets. All the police stations in the study area are located less than $1 \mathrm{~km}$ from the markets. These markets on a daily basis attract buyers from all parts of the town and beyond. As populations converge, incidences of 
theft, store lifting, fire incidences, robbery, fraud are experienced.

It is expected that crime incidents would be uncommon within the $1 \mathrm{~km}$ buffer from the Police stations, but that was not the case in Makurdi where crimes were recorded to have occurred both at near and far proximity of the Police stations. As depicted from the proximity analysis shown in Figure 3, B Division Police station recorded the highest number of crimes ( 89 crimes) within close proximity to the station during the period. C Division Police station followed suit with 57 cases, A Division with 37 criminal records and E Division with the least of only one recorded crime within the $1 \mathrm{~km}$ buffer. Also, the presence of the Police Headquarters seems to effectively ward of crimes as only 2 criminal activities were reported within the period at the $1 \mathrm{~km}$ circumference of the Police Headquarters.

\subsection{Locations for Intensive Policing}

Crime identification is a very important step in crime policing and this has been made easier with the efficacy of GIS. The research shows areas where crime is high, medium and low respectively as shown in Figure 4. The result of the analysis also shows streets within Makurdi which are hotspots for the perpetuation of crime. These are areas where a high amount of security presence is needed to prevent crime and safe guard lives and property. The areas in question are noted

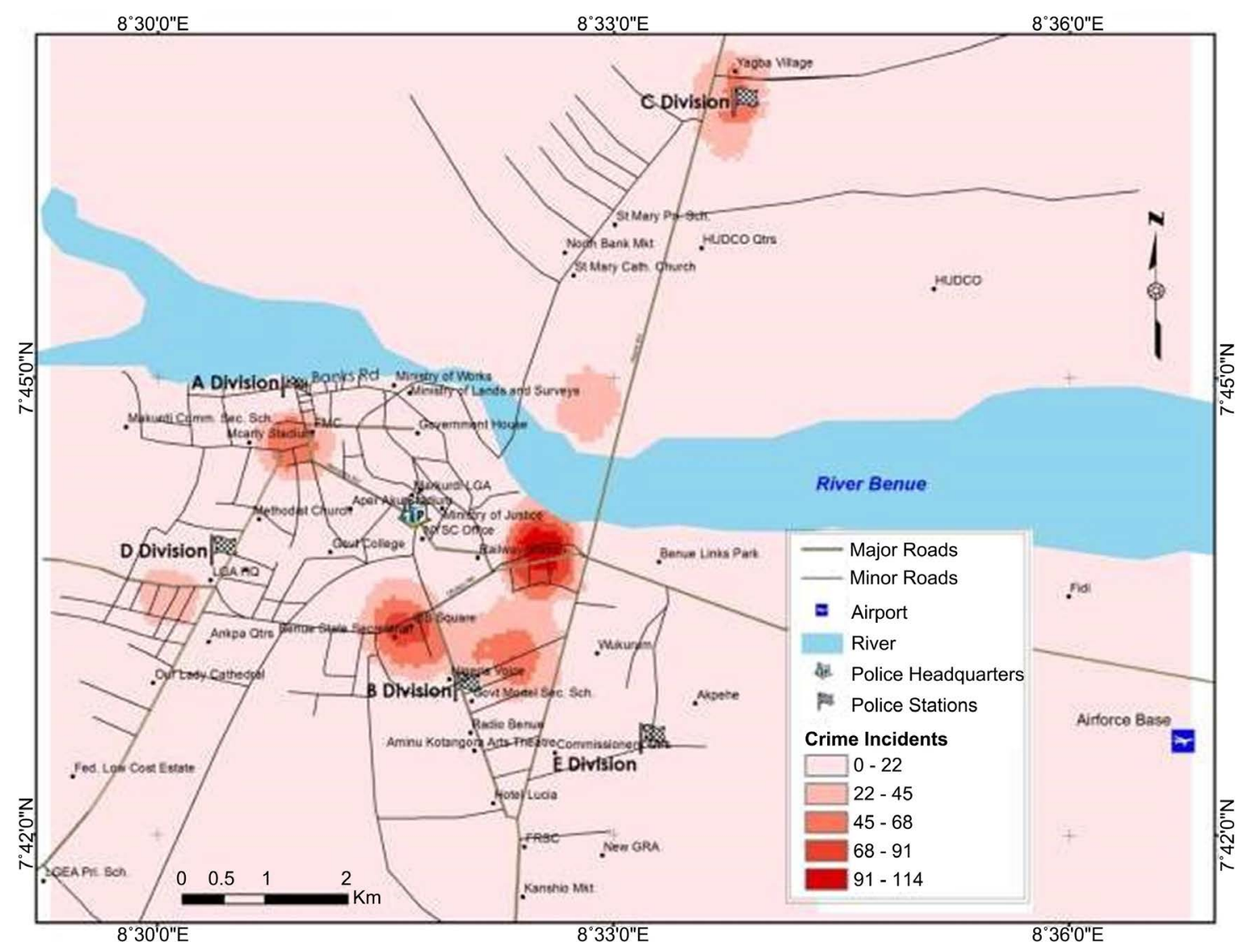

Figure 4. Map of Makurdi showing crime hotspots. 
for all sorts of crimes like theft, unlawful society, armed robbery, unlawful possession of firearms, and rape among other crimes. The crime hotspot map pictured in Figure 4 depicts the areas with a cluster of criminal activities. These hot spots are Iorkyaa Ako Street, Inikpi Street, Konshisha Street, Katsina Street, Nyiman layout, all in High level Makurdi. Other areas are around Wurukum, places such as Awe Street, Onitsha Street, along New Otukpo road to Ishaya Bakut road which all have high records of crime. In North Bank, the riverside has been noted for high cases of crime. Other hotspots in North Bank include; Behind CAPS, opposite heavy-duty park, behind Gandy hotel, Udei Street, Yagba village, etc. Inadequate Security strategies have been noted for and the lapses identified for effective prevention and control of crime in these crime hotspots and in Makurdi at large. These hotspots shown in Figure 4 shows require security presence, intensive patrol and the application of improved strategies in fighting crime.

\section{Conclusions and Recommendations}

The current inclination to crime and other vices in Makurdi and Nigeria at large daily calls for concern of security agencies operational in Nigeria especially the Nigerian Police Force. The goal of this study was to assess the occurrence and distribution of crime in Makurdi metropolis. Spatial and attribute data were collected. The bulk of the data used were collected from the Nigerian Police Headquarters at Makurdi. Notably, only crime incidents that were reported were considered, thus the study cannot claim precision in the number of crimes in the town due to poor record-keeping on the Police and the non-reporting of crimes on the part of the crime victims. Crime mapping has since become widespread and almost commonplace in law enforcement agencies worldwide as it is an invaluable tool available for effective crime policing. Crime hotspots were identified in the metropolis and the crime occurrences within and without $1 \mathrm{~km}$ of the Police stations were also identified. The ANOVA analysis also depicted a statistically significant difference in the distribution of crime incidents among the 5 Police jurisdictions of Makurdi metropolis. Crime studies are undoubtedly essential for proper decision-making with regards to policing and overall crime prevention and control in the study area and beyond. Based on the findings of this research the following are recommended for improved crime prevention and control.

1) The Police can effectively control crime by increasing their presence at the locations identified with high cases of crime. Police presence undeniably reduces crime and increases the potentials for a quick response whenever crimes are reported.

2) The community also has a role to play by venturing into community policing strategies in an attempt to curb crime in the area.

3) The police administration in Benue State should set up GIS departments in all police stations to provide spatial analysis to aid crime prevention and appropriate policing. The patrol units should be equipped with GPS for better surveil- 
lance and to aid rapid response during criminal activities.

4) Also, jurisdictional policing should be made more flexible such that victims can report cases to any nearest Police station and actions taken immediately before transferring the case file to the appropriate jurisdiction for further investigation.

\section{Presented}

This paper was presented at the 58th Association of Nigerian Geographers Annual Conference 12th-17th March 2017 in Nasarawa State University, Keffi, Nasarawa State, Nigeria.

\section{Conflicts of Interest}

The authors declare no conflicts of interest.

\section{References}

[1] Dambazau, A.B. (2007) Criminology and Criminal Justice. 2nd Edition, University Press, Ibadan.

[2] Brantingham, P.J. and Brantingham, P.L. (1981) Environmental Criminology. Waveland Press, Prospect Heights, USA.

[3] Bottoms, A.E. and Wiles, P. (1992) Explanations of Crime and Place. In: Evans, D.J., Fyfe, N.R. and Herbert, D.T., Eds., Crime, Policing and Place: Essays in Environmental Criminology, Routledge, London, 11-35.

[4] Rengert, G.F. (1992) The Journey to Crime: Conceptual foundations and Policy Implications. In: Evans, D.J., Fyfe, N.R. and Herbert, D.T., Eds., Crime, Policing and Place: Essays in Environmental Criminology, Routledge, London, 109-117.

[5] Bottoms, A.E. and Wiles, P. (2002) Environmental Criminology. In: Maguire, M., Morgan, R. and Reiner, R., Eds., The Oxford Handbook of Criminology, Oxford University Press, London, 620-656.

[6] Ratcliffe, J.H. (2004) The Hotspot Matrix: A Framework for the Spatio-Temporal Targeting of Crime Reduction. Police Practice and Research, 5, 7-25. https://doi.org/10.1080/1561426042000191305

[7] Hirschfield, A., Brown, P. and Todd, P. (1995) GIS and the Analysis of Spatially-Referenced Crime Data: Experiences in Merseyside, UK. International Journal of Geographical Information Systems, 9, 191-210.

https://doi.org/10.1080/02693799508902033

[8] Craglia, M., Haining, R. and Wiles, P. (2000) A Comparative Evaluation of Approaches to Urban Crime Pattern Analysis. Urban Studies, 37, 711-729. https://doi.org/10.1080/00420980050003982

[9] Openshaw, S., Cross, A., Charlton, M. and Brunsdon, C. (1990) Lessons Learnt from a Post Mortem of a Failed GIS. 2nd National Conference and Exhibition of the AGI, October, Brighton, UK.

[10] Weisburd, D., Maher, L., Sherman, M., Buerger, E.C. and Petrisino, A. (1993) Contrasting Crime General and Crime Specific Theory: The Case of Hot Spots of Crime. In: Alder, F. and Laufer, W.S., Eds., Advances in Criminological Theory, Vol. 4, Transaction Publishers, London, 45-70.

[11] Ahmadi, M. (2003) Crime Mapping and Spatial Analysis. Thesis, University of Twente, Netherlands. 
[12] Eck, J.E., Chainey, S., Cameron, J.G., Leitner, M. and Wilson, R.E. (2005) Mapping Crime: Understanding Hot Spots. U.S. Department of Justice Office of Justice Programs National Institute of Justice, USA.

[13] Sherman, L.W. and Weisburd, D. (1995) General Deterrent Effects of Police Patrol in Crime "Hotspots": A Randomizes, Controlled Trial. Justice Quartely, 12, 625-648. https://doi.org/10.1080/07418829500096221

[14] Fajemirokum, F.O, Adewale, O., Idowu, T., Oyewusi, A. and Maiyegun, B. (2006) A GIS Approach to Crime Mapping and Management in Nigeria: A Case Study of Victoria Island Lagos. XXIII FIG Congress, Munich, Germany, 8-13 October 2006.

[15] Groff, E.R. and La Vingne, N.G. (2002) Forecasting the Future of Predictive Crime Mapping. Crime Prevention Studies, 13, 29-57.

[16] Ukwayi, J.K. Ojong, F.E., Austin E.B. and Emeka J.O. (2012) Impact of Crime on Sustainable Tourism inCross River State, Nigeria. Research on Humanities and Social Sciences, 2, 35-44.

[17] Ayuba, B., Mugu, B.A., Tanko, H. and Bulus, S.J. (2016) Geo-Spatial Analysis of Crime in Kaduna Metropolis, Nigeria. Science World Journal, 11, 17-29

[18] Olajuyigbe, A., Omole, K., Bayode, T. and Adenigba, A. (2016) Crime Mapping and Analysis in the Core Area of Akure, Nigeria. Journal of Remote Sensing \& GIS, 5, Article No. 1000178. https://doi.org/10.4172/2469-4134.1000178

[19] ESRI (2013) How Point Density Works. ArcGIS 10.2.1 help. https://pro.arcgis.com/zh-cn/pro-app/latest/tool-reference/spatial-analyst/how-poin t-density-works.htm 